\title{
A STUDY OF POST COVID EFFECTS ON PRIVATE COLLEGES: A SPECIAL REFERENCE TO COLLEGE FACULTY MEMBERS IN TIRUCHIRAPPALLI CITY
}

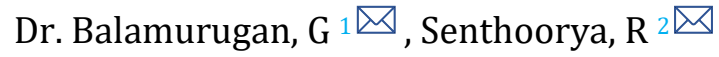 \\ ${ }^{1}$ Assistant Professor, Department of Management Studies, Anna University (BIT Campus), Tiruchirappalli, \\ Tamil Nadu, India \\ ${ }^{2}$ PG Student, Department of Management Studies, Anna University (BIT Campus), Tiruchirappalli, Tamil \\ Nadu, India
}

Received 25 October 2021

Accepted 15 November 2021

Published 17 December 2021

\section{CorrespondingAuthor}

Dr. Balamurugan. G

drgbalamuruganmba@gmail.com

DOI 10.29121/ijetmr.v8.i12.2021.1072

Funding: This research received no specific grant from any funding agency in the public, commercial, or not-for-profit sectors.

Copyright: (C) 2021 The Author(s). This is an open access article distributed under the terms of the Creative Commons Attribution License, which permits unrestricted use, distribution, and reproduction in any medium, provided the original author and source are credited.

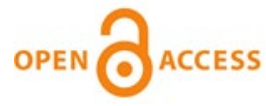

\section{ABSTRACT}

The Covid-19 impact was everywhere, which resulted in the closure of all educational establishments/institutions regardless of their type. Work life balance and stress are the main players in this situation, they are studied and analyzed precisely to understand the difficulties of the faculty members. When there is an imbalance in work-life balance, it will affect the satisfaction level of both personal and professional life, then it will cause low productivity and increase stress. Due to the pandemic, work from home method was implemented for many professions. By comparing IT sector work from home jobs, teaching profession has much difficulties. Educational institutions have the important responsibility to develop the nation by developing the students. Except educational sector other sectors have some period of time to operate their functions, but educational sector has to be sustainable in any situation to assure and secure the future of every nation. Initially, most governments have decided to temporarily close the educational institutions to reduce the impact of Covid-19. Later it was reopened, which increased the number of infection rates and then closed again. This study was conducted to analyze the impacts faced by the private college faculty members in Tiruchirappalli district after the pandemic surge. By conducting this study, about 140 responses had been collected and analyzed using the F test statistical tool.

Keywords: Covid Pandemic, Private College Faculty Members, Work-Life Balance, Stress

\section{INTRODUTION}

An education institution is classified as private if it is controlled and managed by a non- governmental organization (e.g., a Church, Industrial Union or business conglomerates), or if its Governing Board members are mostly not selected by a public agency. They can be created by any individual or legal entity, provided that they respect the constitutional principles and stick with the State regulations and those of the Autonomous Communities. A private college is an independent one and it is a privately funded type of higher education institution. Private colleges likely to have smaller class sizes. Private college may have higher tuition costs than public colleges. 
The covid pandemic has led to a drastic loss of human life in the global level and presents a never before experienced challenges to public health, food systems and the world of work. The interruption in the flow of economic and social activities caused by the pandemic is ruining: tens of millions of people are at risk that they may falling into extreme destitution, while the number of unhealthful people, currently estimated at nearly around 690 million, could increase by up to 135 million by the end of this year. Millions of corporate businesses face an existential threat. Nearly $50 \%$ of the world's 3.3 billion worldwide workforce are at risk of losing their livelihoods. Informal economy (An informal economy is the portion of any economy that is neither taxed nor monitored by any form of government) workers are particularly in dangerous situation because the majority of them lack in social protection and access to proper health care and have lost access to productive capital. Without the means to earn an income during drastic pandemic situation, many are unable to feed themselves and their families. For most, no income creates devastating stress, it will lead to imbalance between professional life and personal life.

It has been the worst of times for teachers. The Covid-19 pandemic has taken away that which makes teachers who they are teaching. Sitting before screens endlessly and interacting with sounds and images of students is not what they bargained for. Teachers standing before a class and speaking before a hundred gaping eyes, and a hundred more eager ears ensure the adrenalin rush and performance anxiety. The challenge of stage, the fright of being on a platform and delivering knowledge, but not knowledge alone, prepares the mold of a teacher. A mold made out of hard discipline and soft wonder. In pandemic stimulated circumstances, the stage that moved teachers on a pedestal, literally so, has evaporated into thin viral air and the mold of discipline has disintegrated to listless routine.

\section{OBJECTIVES OF THE STUDY}

- To study about the post covid impacts faced by private college faculty members

- To analyze how they used to stabilize the work - life balance.

- To find the stress level of the faculty members after the pandemic surge.

\section{SCOPE OF THE STUDY}

The scope of the study is to analyze work load, stress level, remuneration, satisfaction level of job role and personal life of the private college faculty members and how they handle their work-life balance during the covid widespread situation. The study was conducted in Tiruchirappalli district, which is the central part of Tamil Nadu state. More than 30 private colleges are situated in Tiruchirappalli district. We can develop this study to be suited for the other districts or states private colleges or even other private institutions like universities, schools.

\section{RESEARCH DESIGN}

Research design is the framework of all existing research methods and techniques chosen by a researcher. The design allows researchers to be acute and intense in on research methods that are suitable for the subject matter and set up their knowledge up for success. The research topic design expounds the type of 
research (that is experimental, semi-experimental, survey research, correlational, , or review) and also its sub-type ( that is experimental design, descriptive case-study, or research related problem). There are three main types of designs for research: Data collection, measurement, and analysis. The type of research problem an organization is facing will determine the research design and not vice-versa. The design phase of a study determines which tools to use and how they are used.

\section{SAMPLE DESIGN}

About 140 responses were collected. The primary data was collected through the questionnaire designed exclusively for the study. Various questions related to the variables were selected and the responses were collected through online form.

\section{METHOD OF DATA COLLECTION}

The data were collected from primary data. The primary data were collected by using snowball method of collection from the private college faculties through google forms. Secondary data were taken from websites, journals, and research papers.

\section{STATISTICAL TOOLS USED}

Frequency analysis and One way ANOVA test was used to conduct F test.

\section{SOFTWARE PAKAGEGE USED: SPSS STATISTICAL PACKAGE FOR SOCIAL SCIENCES}

software had been used to conduct the study analysis.

\section{ANALYSIS}

\section{Frequency Analysis}

\section{1) GENDER ANALYSIS}

\begin{tabular}{|lll|}
\hline Table 1 & & \\
\hline Gender & Frequency & Percentage \\
\hline Male & 94 & 67.1 \\
\hline Female & 46 & 32.9 \\
\hline Prefer not to say & 0 & 0 \\
\hline
\end{tabular}




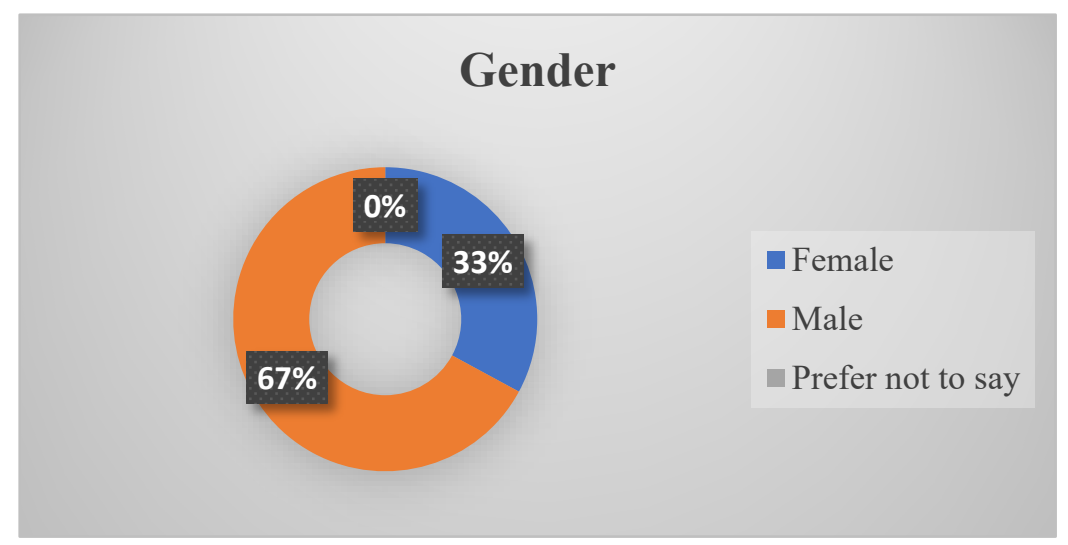

Figure 1 Gender of respondents

\section{Interpretation}

The above pie chart shows that out of $100 \%$ respondents, $67 \%$ were male and $33 \%$ were female.

\section{2) EXPERIENCE ANALYIS}

\begin{tabular}{|lll|}
\hline Table 2 & & \\
\hline Experience & Frequency & Percentage \\
\hline 0 & 6 & 4.3 \\
\hline Less than 5 years & 94 & 67.1 \\
\hline Less than 10 years & 16 & 11.4 \\
\hline More than 10 years & 24 & 17.1 \\
\hline
\end{tabular}

\section{Experience}

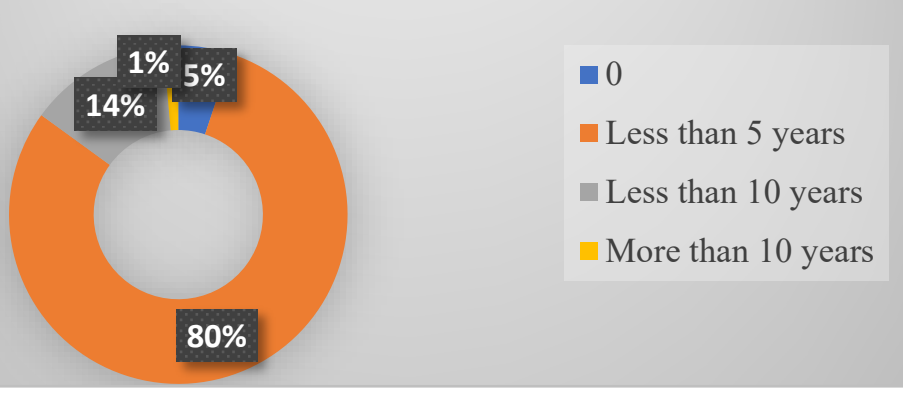

Figure 2 Experience of the respondents 


\section{Interpretation}

The above pie chart shows that $67 \%$ of the respondents has less than 5 years of experience, $17 \%$ of respondents has more than 10 years of experience, $12 \%$ of respondents has less than 10 years of experience and $4 \%$ of respondents has no experience.

\section{F TEST ANALYSIS}

\section{1) Gender and work life balance}

H0: There is no significant relationship between gender and work- life balance

H1: There is a significant relationship between gender and work-life balance

\begin{tabular}{|c|c|c|c|c|c|c|}
\hline \multicolumn{7}{|l|}{ Table 3 ANOVA } \\
\hline & & $\begin{array}{c}\text { Sum of } \\
\text { Squares }\end{array}$ & Df & $\begin{array}{c}\text { Mean } \\
\text { Square }\end{array}$ & $\mathbf{F}$ & Sig. \\
\hline \multirow{3}{*}{$\begin{array}{l}\text { Social Interaction (Meeting friends, } \\
\text { going out, joining in groups, going } \\
\text { shopping, every day activities outside } \\
\text { the home) }\end{array}$} & $\begin{array}{l}\text { Between } \\
\text { Groups }\end{array}$ & 0.021 & 1 & 0.021 & 0.009 & 0.923 \\
\hline & $\begin{array}{l}\text { Within } \\
\text { Groups }\end{array}$ & 302.379 & 138 & 2.191 & & \\
\hline & Total & 302.4 & 139 & & & \\
\hline \multirow{3}{*}{$\begin{array}{l}\text { Leisure activities (Sporting activities, } \\
\text { getting exercise, hobbies, gardening, } \\
\text { DIY activities, crafts, travel) }\end{array}$} & $\begin{array}{l}\text { Between } \\
\text { Groups }\end{array}$ & 4.933 & 1 & 4.933 & 2.767 & 0.099 \\
\hline & $\begin{array}{l}\text { Within } \\
\text { Groups }\end{array}$ & 246.039 & 138 & 1.783 & & \\
\hline & Total & 250.971 & 139 & & & \\
\hline \multirow{3}{*}{$\begin{array}{l}\text { Personal care (Looking after yourself, } \\
\text { your health, personal hygiene, need } \\
\text { for special clothing) }\end{array}$} & $\begin{array}{l}\text { Between } \\
\text { Groups }\end{array}$ & 2.449 & 1 & 2.449 & 1.427 & 0.234 \\
\hline & $\begin{array}{l}\text { Within } \\
\text { Groups }\end{array}$ & 233.435 & 136 & 1.716 & & \\
\hline & Total & 235.884 & 137 & & & \\
\hline \multirow[t]{3}{*}{$\begin{array}{l}\text { What is your opinion about Work } \\
\text { from home? }\end{array}$} & $\begin{array}{l}\text { Between } \\
\text { Groups }\end{array}$ & 1.613 & 1 & 1.613 & 1.291 & 0.258 \\
\hline & $\begin{array}{l}\text { Within } \\
\text { Groups }\end{array}$ & 172.359 & 138 & 1.249 & & \\
\hline & Total & 173.971 & 139 & & & \\
\hline \multirow[t]{3}{*}{$\begin{array}{l}\text { How do you manage your professional } \\
\text { life and family during this pandemic? }\end{array}$} & $\begin{array}{l}\text { Between } \\
\text { Groups }\end{array}$ & 3.219 & 1 & 3.219 & 2.284 & 0.133 \\
\hline & $\begin{array}{l}\text { Within } \\
\text { Groups }\end{array}$ & 194.524 & 138 & 1.41 & & \\
\hline & Total & 197.743 & 139 & & & \\
\hline
\end{tabular}

Interpretation: The above output shows that there is a significant relationship among the variables. By referring the $\mathrm{F}$ table, the critical $\mathrm{F}$ value was 1 . As per the rule, if $P$ value less than alpha value and $F$ critical value lesser than the $F$ calculated value, then we can reject the null hypothesis and accept the alternative hypothesis. 


\section{2) Experience and salary}

H0: There is no significant relationship between experience and salary

H1: There is a significant relationship between experience and salary

\begin{tabular}{|c|c|c|c|c|c|c|}
\hline \multicolumn{7}{|l|}{ Table 4 ANOVA } \\
\hline & & $\begin{array}{l}\text { Sum of } \\
\text { Squares }\end{array}$ & Df & $\begin{array}{l}\text { Mean } \\
\text { Square }\end{array}$ & $\mathbf{F}$ & Sig. \\
\hline \multirow[t]{3}{*}{$\begin{array}{c}\text { Is your salary affected during the } \\
\text { pandemic? }\end{array}$} & $\begin{array}{l}\text { Between } \\
\text { Groups }\end{array}$ & 6.2 & 3 & 2.067 & 15.204 & $<.001$ \\
\hline & $\begin{array}{l}\text { Within } \\
\text { Groups }\end{array}$ & 18.486 & 136 & 0.136 & & \\
\hline & Total & 24.686 & 139 & & & \\
\hline \multirow[t]{3}{*}{$\begin{array}{c}\text { Did you manage your livelihood with } \\
\text { your salary before covid? }\end{array}$} & $\begin{array}{l}\text { Between } \\
\text { Groups }\end{array}$ & 4.349 & 3 & 1.45 & 3.241 & 0.024 \\
\hline & $\begin{array}{l}\text { Within } \\
\text { Groups }\end{array}$ & 60.823 & 136 & 0.447 & & \\
\hline & Total & 65.171 & 139 & & & \\
\hline \multirow{3}{*}{$\begin{array}{l}\text { If COVID-19 pandemic affects the } \\
\text { salaries of the private institution } \\
\text { faculties, then How much salary } \\
\text { would you receive? }\end{array}$} & $\begin{array}{l}\text { Between } \\
\text { Groups }\end{array}$ & 22.868 & 3 & 7.623 & 16.194 & $<.001$ \\
\hline & $\begin{array}{l}\text { Within } \\
\text { Groups }\end{array}$ & 64.018 & 136 & 0.471 & & \\
\hline & Total & 86.886 & 139 & & & \\
\hline
\end{tabular}

Interpretation: The above output shows that there is a significant relationship among the variables.

\section{3) Experience and Stress}

H0: There is no significant relationship between experience and stress

H1: There is a significant relationship between experience and stress

\begin{tabular}{|c|c|c|c|c|c|c|}
\hline \multicolumn{7}{|l|}{ Table 5 ANOVA } \\
\hline & & $\begin{array}{l}\text { Sum of } \\
\text { Squares }\end{array}$ & Df & $\begin{array}{l}\text { Mean } \\
\text { Square }\end{array}$ & $\mathbf{F}$ & Sig. \\
\hline \multirow[t]{3}{*}{$\begin{array}{c}\text { Rate your stress level before } \\
\text { the pandemic }\end{array}$} & $\begin{array}{l}\text { Between } \\
\text { Groups }\end{array}$ & 4.88 & 3 & 1.627 & 3.175 & 0.026 \\
\hline & $\begin{array}{l}\text { Within } \\
\text { Groups }\end{array}$ & 69.663 & 136 & 0.512 & & \\
\hline & Total & 74.543 & 139 & & & \\
\hline \multirow[t]{3}{*}{$\begin{array}{c}\text { Rate your stress level during } \\
\text { the pandemic }\end{array}$} & $\begin{array}{l}\text { Between } \\
\text { Groups }\end{array}$ & 45.783 & 3 & 15.261 & 18.573 & $<.001$ \\
\hline & $\begin{array}{l}\text { Within } \\
\text { Groups }\end{array}$ & 110.101 & 134 & 0.822 & & \\
\hline & Total & 155.884 & 137 & & & \\
\hline \multirow[t]{3}{*}{$\begin{array}{l}\text { Do you feel work load is } \\
\text { increased in the pandemic? }\end{array}$} & $\begin{array}{l}\text { Between } \\
\text { Groups }\end{array}$ & 2.181 & 3 & 0.727 & 1.418 & 0.24 \\
\hline & $\begin{array}{l}\text { Within } \\
\text { Groups }\end{array}$ & 67.701 & 132 & 0.513 & & \\
\hline & Total & 69.882 & 135 & & & \\
\hline
\end{tabular}




\begin{tabular}{|ccccccc}
$\begin{array}{c}\text { After Covid-19 restrictions are } \\
\text { lifted, would you like to 1 or } \\
\text { return to your place of work? }\end{array}$ & $\begin{array}{c}\text { Between } \\
\text { Groups }\end{array}$ & 16.424 & 3 & 5.475 & 17.678 & $<.001$ \\
& $\begin{array}{c}\text { Within } \\
\text { Groups } \\
\text { Total }\end{array}$ & 42.119 & 136 & 0.31 & & \\
& $\begin{array}{c}\text { Between } \\
\text { Groups }\end{array}$ & 1.649 & 3 & 0.55 & 1.016 & 0.388 \\
$\begin{array}{c}\text { Does CovID-19 pandemic lead } \\
\text { to the retrenchment of private } \\
\text { institution faculties? }\end{array}$ & $\begin{array}{c}\text { Within } \\
\text { Groups }\end{array}$ & 71.41 & 132 & 0.541 & & \\
\hline & Total & 73.059 & 135 & & & \\
\hline
\end{tabular}

\section{Interpretation}

The above output shows that there is a significant relationship among the variables. If $\mathrm{f}$ calculated value is greater than $\mathrm{f}$ calculated value than we have to reject null hypothesis else not. Even though we have to check the f values, but the main thing is to compare $P$ values with alpha value $(0.05)$. All the f calculated values are greater than one except one variance. Also, all the $P$ values are less than the alpha value 0.05 except one variance. From this result, we can reject null hypothesis and accept the alternative hypothesis (i.e., There is a significant difference between experience and stress).

\section{Findings}

It is clearly shown that there is a significant relationship between the variances (As per the Table 3, Table 4, and Table 5).

\section{SUGGESTIONS}

By understanding the situation of economy recession, the family members of the private college faculty members should support them to improve the work life balance and reduce the stress level.

\section{CONCLUSION}

This covid pandemic creates a massive impact on the education sector, especially private educational institutions face lot of difficulties. Retrenchment/employee turnover doesn't a solution for the problem. Situation teaches a perfect lesson for everyone, the only thing it often remind us is whatever the situation deemed, we have to survive and develop an efficient way with alternative to each massive height.

\section{REFERENCES}

Agus Purwanto, Masduki Asbari, Mochammad Fahlevi, Abdul Mufid, Eva Agistiawati, Yoyok Cahyono, Popong Suryani. (2020). Impact of Work From Home (WFH) on Indonesian Teachers Performance During the Covid-19 Pandemic : An Exploratory Study. International Journal of Advanced Science and 
Technology, 29(05), $6235 \quad-\quad 6244 . \quad$ Retrieved from http://sersc.org/journals/index.php/IJAST/article/view/15627

Akour A, Al-Tammemi AB, Barakat M, Kanj R, Fakhouri HN, Malkawi A, Musleh G. The Impact of the COVID-19 Pandemic and Emergency Distance Teaching on the Psychological Status of University Teachers: A Cross-Sectional Study in Jordan. Am J Trop Med Hyg. 2020 Dec;103(6):2391-2399. Retrieved from doi: https://doi.org/10.4269/ajtmh.20-0877. Epub 2020 Oct 27. PMID: 33124547; PMCID: PMC7695050.

Alexander V. Prokhorov, David W. Wetter, Diana Padgett, Carl de Moor, Tao Le, Heather Kitzman. "SPIT TOBACCO PREVENTION AND CESSATION COUNSELING : STATEWIDE SURVEY OF HEALTH-CARE PROFESSIONALS AND EDUCATORS", Substance Use \& Misuse, 2002 . Retrieved from https://doi.org/10.1081/JA-120001976

Amit Kumar Arora and R. Srinivasan (2020). "Impact of Pandemic COVID-19 on the Teaching - Learning Process: A Study of Higher Education Teachers". Prabandhan: Indian Journal of management, Volume 13, Issue 4, April 2020 Arora Retrieved from DOI: https://doi.org/10.17010/pijom/2020/v13i4/151825

Frank B. K. Twenefour. "Major Determinants that Influence the Choice of Brand of Mobile Phone", Open Journal of Statistics, 2017. Retrieved from https://doi.org/10.4236/ojs.2017.74046

Nambiar (2020). The impact of online learning during COVID-19: students' and teachers' perspective. International Journal of Indian Psychology, 8(2), 783793. DIP:18.01.094/20200802, Retrieved from DOI: https://doi.org/10.25215/0802.094

Ogunode Niyi Jacob (2020). "Impact of COVID-19 on Private Secondary School Teachers in F.C.T, Abuja, Nigeria". Electronic Research Journal of Behavioural Sciences, Volume 3 (2020) Retrieved from https://doi.org/10.31149/ijie.v3i6.399

Pravat Kumar Jena (2020). "Impact of Pandemic COVID-19 on Education in India". International Journal of Current Research (IJCR), Vol-12, Issue-7, Page12582-12586 (2020). Retrieved from DOIhttp://journalcra.com/article/impact-pandemic-covid-19-education-india

Preeti Tarkar (2020). "Impact of Covid-19 Pandemic on Education System" International Journal of Advanced Science and Technology Vol. 29, No. 9s, (2020), pp. 3812-3814 "IMPACT OF COVID-19 ON PEOPLE'S LIV ELIHOODS, THEIR HEALTH AND OUR FOOD SYSTEMS", Saudi Medical Journal

Subedi S, Nayaju S, Subedi S et.al. Impact of E-learning during COVID-19 pandemic among nursing students and teachers of Nepal. International Journal of Science \& Healthcare Research. 2020 ; 5(3): 68-76

Tadesse, S. and Muluye, W. (2020) The Impact of COVID-19 Pandemic on Education System in Developing Countries: A Review. Open Journal of Social Sciences, 8, 159-170. Retrieved from doi: https://doi.org/10.4236/jss.2020.810011

Vaishali Bokde (Kharbikar) and H.L. Kharbikar (2020). "Possible impacts of COVID19 Pandemic and Lockdown on Education Sector in India". Food and Scientific Reports, May 2020 | Volume 1 : Special issue ISSN 2582-5437 